praksis (bl.a. bruk av CT)». Karakteristikken er ikke treffende. Variasjon er ikke nødvendigvis et problem, men avvik fra omforente faglige retningslinjer er det. Samtidig som vi dokumenterer at de aller fleste CT-undersøkelsene er utført lege artis, har vi avdekket et forbedringspotensial: $15 \%$ av CT thorax/buk/bekken er tatt uten intravenøs kontrast, og $16 \%$ av pasientene som ble undersøkt med CT caput, gjennomgikk ingen bildediagnostikk av cervikalcolumna. Radiologisk avdeling, UNN ønsker å ta utgangspunkt i disse funnene i det kommende arbeidet med implementering av den nye traumeorganisasjonen i Helse Nord.

Effektiv diagnostikk og stabiliserende behandling ved lokalsykehus før overføring til traumesenter er bærebjelker i det planlagte nasjonale traumesystemet (2). Vår studie skal ikke leses som kritikk. Vi analyserer sentrale planforutsetninger og påpeker forbedringstiltak som sikter mot at lokalsykehuset best mulig skal fylle sin rolle i overlevelseskjeden.

\section{Trond Dehli}

Hjerte-, lunge- og karkirurgisk avdeling

\section{Anna Bågenholm \\ Liv-Hege Johnsen \\ Radiologisk avdeling}

\section{Svein Are Osbakk}

Knut Fredriksen

Akuttmedisinsk klinikk

\section{Kristian Bartnes}

Hjerte-, lunge- og karkirurgisk avdeling

Universitetssykehuset Nord-Norge

\section{Litteratur}

1. Dehli T, Bågenholm A, Johnsen L-H et al. Alvorlig skadede overført til universitetssykehus. Tidsskr Nor Legeforen 2010; 130: 1455-7.

2. Røise O, Gaarder C, Hansen KS et al. Traumesystem i Norge: forslag til organisering av behandlingen av alvorlig skadde pasienter. Hamar: Helse Øst, 2006

\section{Tvilsom praksis}

I mitt innlegg i Tidsskriftet nr. 18/2010 skrev jeg at vi i Citizens Commissian on Human Rights (CCHR) kontinuerlig er i kontakt med politi, fagmiljøer og medier for å belyse at pasient-

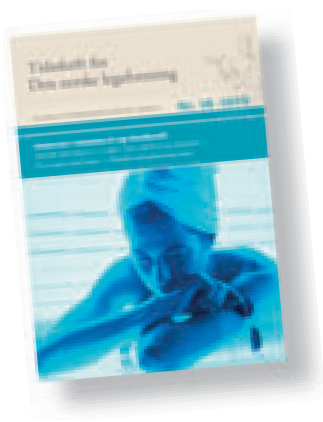
foreningen ADHD Norge mottar mye av sin økonomiske støtte fra produsentene av AD/HD-preparater som Ritalin, Concerta og Stratera (1). Tor Eikeland i ADHD Norge påpekte i Tidsskriftet nr. 22/2010 at de faktiske pengesummene de mottok, ikke var store, og at ADHD Norge ikke har noen etiske problemer med å motta pengegaver fra den farmasøytiske industrien (320 000 kroner i 2008) (2).

Omtrent 16000 barn og unge bruker disse preparatene i Norge i dag. Ritalin og Concerta er amfetaminliknende, narkotiske stoffer som har farlige bivirkninger. Etter vår mening $\mathrm{er} \mathrm{AD} / \mathrm{HD}$-diagnosen en høyst subjektiv og lite målbar betegnelse på en rekke forskjellige symptomer - det er ikke en reell sykdom i ordets rette betydning. Følgelig virker disse stoffene kun til å endre atferd - slik alle narkotiske stoffer gjør.

ADHD Norge forfekter diagnosens gyldighet, og preparatenes fortreffelighet, og mottar økonomisk støtte av ulik størrelse fra produsentene av disse narkotiske stoffene. Videre har ADHD Norge et fagråd som består av bl.a. barne- og ungdomspsykiatere som også aktivt promoterer preparatenes fortreffelighet - og som samarbeider med den farmasøytiske industrien i sine yrker.

CCHR ble stiftet av en gruppe scientologer i samarbeid med psykiateren Thomas Szasz i 1969. Den er en ikke-religiøs og ikke-politisk internasjonal organisasjon som arbeider for å få FNs menneskerettigheter og lov og etikk til å virke i fagfeltet mental helse. Psykiatere, psykologer, leger, avhoppere fra den farmasøytiske industrien samt ofre for feildiagnostisering, feilmedisinering og overgrep fra psykiatrien er aktive i organisasjonen over hele verden. Vi anser bruk av narkotiske stoffer og annen psykofarmaka på barn som alvorlige brudd på deres rettigheter, og vi vil spre kunnskap om dette til alle involverte parter - helt til en større opprydding av situasjonen finner sted.

Pasientstøttegruppers kobling med den farmasøytiske industrien, og psykiatere som jobber i begge disse leirene, er en høyst aktuell problemstilling for oss i vårt virke. ADHD Norge er langt fra noe unntak snarere tvert imot siden det er barn og ungdom det handler om her.

\section{Hans-Erik Dyvik Husby \\ CCHR Norge}

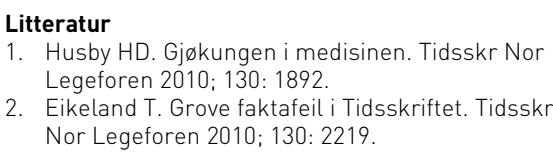

\section{Kun datamodellar, ikkje fakta}

Eg noterer meg at Helge Drange \& Gunnar Kvåle i Tidsskriftet nr. 17/2010 brukar omgrepet klimaendring (1). Kvifor brukar dei ikkje global oppvarming - for det er vel det som har vore problemet? Eller skal $\mathrm{CO}_{2}$ no få skulda for ei ikkje usannsynleg nedkjøling dei komande åra også?

Det er ikkje rett at vitskapen har doku- mentert at $\mathrm{CO}_{2}$ har avgjerande betydning for klimaet. Eg kjenner ikkje til forsking som viser at ein auke av innhaldet av drivhusgassar påverkar klimaet vesentleg. Men satelittmålingar indikerer at ein dobling av $\mathrm{CO}_{2}$-innhaldet $\mathrm{i}$ atmosfæren vil kunne gje ein temperaturauke på ca. 0,5 grader celsius. Videre at mennesket sitt bidrag til denne auken er ca. $4 \%$, det vil seie at vi vil vere «ansvarlege» for ein temperaturauke på 0,02 grader. Drange og co. kan spare seg å vise til National Academy of Science: Konsensus bygd på modellar liksom Intergovernmental panel on climate change (IPCC) gjer, provar etter mi meining knapt nokon ting så lenge desse modellane ikkje gjer greie for den viktigaste drivhusgassen: vassdamp.

Professor Richard Lindzen ved Massachusetts Institute of Technology (MIT) og andre forskarar har i løpet av 20 år gjort målingar når det gjeld varmeutstrålinga frå jorda, noko som er avgjerande for temperaturutviklinga $(2,3)$. Christopher Monckton gjer i eit foredrag greie for dette sentrale punktet i klimaspørsmålet og mange andre påstandar frå IPCC (4).

\section{Gunnar Saunes}

Ulsteinvik

\section{Litteratur}

1. Drange $H$, Kvåle G. Ikkje tru, men fakta. Tidsskr Nor Legeforen 2010: 130: 1704

2. Spencer R, Braswell WD. Potential Biases in Feedback Diagnosis from Observational Data: A Simple Model Demonstration. Journal of Climate 2007; 21 5624-28.

3. Douglas DH, Christy JR, Person BDP et al. A comparison of tropical temperature trends with model projections. Int J Climatol 2007; doi: 10.1002/ joc.1651 www.icecap.us/images/uploads/ DOUGLASPAPER.pdf (29.10.2010).

4. Monckton C. Foredrag i London 2009 www.youtube.com/watch?v=4zOXmJ4jd-8\& feature=player_embedded $(29.10 .2010)$

\section{Behov for leger som ledere}

Jeg er glad for at Tor Ingebrigtsen i Tidsskriftet nr. 20/2010 tar opp debatten om hvorfor leger blir, eller ikke blir, ledere (1). Legeforeningen jobber for at leger skal ta lederansvar. Det er stort behov for dyktige ledere blant legene, og jeg har tidligere oppfordret leger til å bli ledere (2).

Legeforeningen har bred kontakt med ledere i helsetjenesten og gir konkret bistand og veiledning til mange. Foreningen utarbeider veiledere hvor man retter seg både mot tillitsvalgte og ledere som støtte i ledelsesutøvelse. Veilederen om omstillingsprosesser gir lett tilgjengelig informa- 
sjon om hvordan man kan lykkes i vanskelige omstillinger, og en oversikt over ledelse og ansvarsforhold i helsetjenesten. Snart kommer en veileder om arbeidsmiljø med viktig kunnskap for å kunne lede på en god måte.

Legeforeningen er opptatt av å styrke kunnskapen om ledelse blant leger generelt og blant ledere i ulike sammenhenger. Tillitsvalgtopplæringen er styrket bl.a. fordi tillitsvalgtarbeid motiverer til ledelse. Legeforeningen har stipender for leger som tar lederutdanning.

For kvinnelige leger arrangerer Legeforeningen sammen med Helse Sør-Øst seminaret «Frist meg inn i ledelse» - et konsept som nå vil tilbys også for primærhelsetjenesten. En ekstern evaluering har vist at dette gir gode resultater.

Overlegeforeningen har lederseminarer og ledernettverk med erfarne ledere. Allmennlegene arrangerer lederkurs. Man forsøkte å skape et forum på tvers av de ulike yrkesforeningene i 2006, men uten at det den gang var tilstrekkelig interesse for arbeidet. Lederforum, lederkompetanse, gode lederstillinger og lederstøtte er noen temaer for videre satsing, gjerne i økt samarbeid med lederne.

Legeidentiteten er nært knyttet til faget. Det er interessant at 23 prosent av topplederne $i$ en av studiene Ingebrigtsen refererer til, arbeidet klinisk ved siden av direktørjobben. Mange land er flinkere enn Norge til å tilrettelegge for denne kombinasjonen. Lederstillinger med gode støttefunksjoner innen økonomi, personalhåndtering og sekretærhjelp, muliggjør kombinasjon med klinisk arbeid og kan bedre rekrutteringen av leger. Samtidig trenger leger anerkjent lederutdannelse, som gjerne kan starte i studiet. Gode støttefunksjoner fritar ikke for ansvar og behov for formalisert kompetanse i ledelsesfaget. Man må etablere finansieringsordninger som gjør dette mulig.

Mange kolleger etterlyser en sterkere medisinsk faglig ledelse; også i kommunehelsetjenesten. Man opplever at nærmeste leder er en del av «sykehusadministrasjonen» og ikke den som står på for fagutvikling. Det er frustrerende, men forståelig, da lederen kan slites mellom lojalitet til overordnet ledelse og forventninger fra dem man leder. Tydelig samsvar mellom ansvar og myndighet kan lette krysspresset. Det viktigste endringsbehovet er likevel at styringen av helsetjenesten i mye større grad må inkludere kvalitetskrav og ikke ensidig fokusere på aktivetstall og diagnoserelaterte grupper (DGR). Det vil inspirere. Leger ønsker å levere god kvalitet, og budsjettene må være rettet inn mot det.

Økt rekruttering av leger med lederkompetanse er avgjørende for kvalitetssatsing $i$ helsetjenesten. Derfor oppfordrer jeg legene til å delta på vår lederkonferanse til våren.
Torunn Janbu

President

Den norske legeforening

\section{Litteratur}

1. Ingebrigtsen T. Leger som blir sykehusdirektører. Tidsskr Nor Legeforen 2010; 130: 2015

2. Janbu T. Leger og ledelse. Tidsskr Nor Legeforen 2009; 129: 913.

\section{Svangerskap - tryggest på overtid?}

I Tidsskriftet

nr. $21 / 2010$

kommenterer

Haavaldsen og medarbeidere at fosterdødsrisikoen etter termin er svært lav (1).

I løpet av én overtidsuke (per definisjon etter 42 fullgåtte uker)

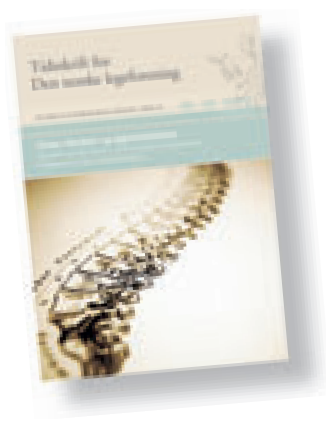

dør ett av 400 barn i Norge, og økt morbiditet kommer i tillegg. Norsk folkehelse og svangerskapsomsorg har fremragende resultater, og risikoen er svært lav i forhold til før, men er prisen for denne overtidsuken fremdeles for høy? I andre sammenhenger med dødsfall hos fullbårne barn blir slik risiko omtalt som høy. Det finnes selvsagt ingen fasit, men ulike preferanser.

Derimot er det unødvendig tøv fra en erfaren debattant som Anne Eskild å påstå at Folkehelseinstituttet foreslår at alle gravide skal induseres før termin eller på termindagen og de seks påfølgende dagene («innen svangerskapsuke 41» eller «i uke $41 »)$. Vi har påpekt at Norsk gynekologisk forenings retningslinjer, med første overtidskontroll etter 42 uker og tilbud om induksjon etter 43 uker ved tilsynelatende ukomplisert forløp, er utdaterte. Vi har vist til oppdaterte kliniske retningslinjer fra National Institute for Health and Clinical Excellence NICE (2), som vår svangerskapsomsorg ellers er basert på. NICE konkluderer med at alle gravide bør gis enhver anledning til å gå spontant i fødsel, men etter 41 fullgåtte uker (og før uke 42 utløper) bør alle kvinner evalueres og få velge mellom induksjon eller videre ekspektans.

Denne konklusjonen trekker NICE fordi det finnes bevis for at forebygging av overtidighet, med tilbud om induksjon, reduserer perinatal død og skade, samtidig som man øker brukertilfredsheten og reduserer keisersnittsraten og kostnader for samfunnet (2-6). Når Haavaldsen og medarbeidere påstår noe annet, konkluderer de motsatt av helsemyndighetene i Tyskland, Nederland, Frankrike, Canada, USA, Australia, New Zealand og Storbritannia, autoritative kunnskapsbaser som UpToDate, WHOs Repro- ductive Health Library og Cochrane Library, og på mer hjemlige trakter blant andre Oslo universitetssykehus.

Forfatterne må gjerne ha et annet syn enn norske fødende på risiko og god behandling (6), men mangler kunnskapsgrunnlag for å avvise at induksjon i det minste er et fullgodt alternativ. Har man to fullgode alternativer, må gravide få informasjon og gis innflytelse over helsevalg. I motsatt fall er det definitivt viktig at allmennheten, gravide og media følger debatten i fagmiljøet vårt.

Folkehelseinstituttet ser frem til at Helsedirektoratet ferdigstiller nye nasjonale retningslinjene og håper de bringer et godt tilbud til alle.

\section{J. Frederik Frøen \\ Folkehelseinstituttet \\ Litteratur \\ 1. Haavaldsen C, Sarfraz A, Eskild A. Lav fosterdøds- risiko etter termin i Norge. Tidsskr Nor Legeforen 2010; 130: 2114 \\ 2. National Institute for Health and Clinical Excel- lence. Induction of labour. http://guidance.nice. org.uk/CG70 (15.11.2010) \\ 3. Gulmezoglu AM, Crowther CA, Middleton P. Induction of labour for improving birth outcomes for women at or beyond term. Cochrane Database Syst Rev 2006; CD004945. \\ 4. Mozurkewich E, Chilimigras J, Koepke E et al. Indications for induction of labour: a best-evidence review. Bjog 2009: 116: 626-36. \\ 5. Caughey AB, Sundaram V, Kaimal AJ et al. Sys- tematic review: Elective induction of labor versus expectant management of pregnancy. Ann Intern Med 2009; 151: 252-63. \\ 6. Heimstad R, Romundstad PR, Hyett J et al. Women's experiences and attitudes towards expectant management and induction of labor for post-term pregnancy. Acta Obstet Gynecol Scand} 2007; 86: 950-6.

\section{Fine ord om sykehusreform}

Adminstrerende direktør Bente Mikkelsen i Helse Sør-Øst skryter i Tidsskriftet nr. 21/2010 av hvor riktig «redesignen» av sykehustilbudet i Oslo-regionen er, hvor trygg prosessen er, og hvor godt resultatet blir (1). Ikke bare for Oslo, men for hele landet. Frasene er vel kjent for oss som arbeider på Oslo universitetssykehus. Men den flinke direktøren påviser heller ikke nå hvordan reorganiseringen skal føre til de flotte resultatene, f.eks. «forskning og innovasjon i verdensklasse» og at «bruken av utstyr og personell [...] blir mer virkningsfull». Det forblir påstander. Hvorfor Oslos høye innvandrerandel og belastende rusmiljøer tilsier den reorganiseringen man nå foretar, slik Mikkelsen argumenterer $\mathrm{i}$ ingressen, er uklart. For hvem har reformen vært «etterlengtet»? Det er en sannhet med modifikasjoner at «gjennom fusjonen er fagmiljøer samlet». Det motsatte har sannelig også skjedd. Den stadig gjentatte honnørfrasen, «én dør inn», er misvisende: Oslos befolkning vil få lokalsykehustjenester på Akershus Universitets- 